ISSN 2305-2678 (Print); ISNN 2305-5944 (Online)

DOI : http://dx.doi.org/10.4314/rj.v28i1.1

\title{
Influence of Bud Position on Mother Stem And Soaking Duration on Sprouting of Bamboo Cuttings
}

Bonaventure Ntirugulirwa, Theodore Asiimwe, Jean Gapusi, Amini Mutaganda, Gakwerere Nkuba, Antoine Nyirigira Ruzindana, David Ntabana, Bizeye Barnabé, Jane Kahia and Daphrose Gahakwa

Institut des Sciences Agronomiques du Rwanda (ISAR), P.O. Box 137, Kigali, Rwanda

Corresponding author e-mail: janekahia@yahoo.co.uk

\begin{abstract}
Bamboo is one of the fastest growing and highest yielding renewable natural resources with multiple uses in the world. It is used to make furniture, charcoal, food, control soil erosion and can assist in carbon sequestration. The increasing rate of tropical deforestation calls for search for alternative natural resources and the characteristics of bamboo make it a perfect choice. The major constraint in the use of bamboo is the lack of an efficient propagation method. The objective of this study wase to establish an efficient propagation method and to evaluate the adaptability of different bamboo varieties, to Nyungwe National Park (NNP) and the surrounding zones.The trial was conducted in Nyaruguru District, Ruheru Sector bordering Nyungwe National. Basal, middle and apical cuttings were harvested from three bamboo species (Bambusa vulgaris, Arundinaria alpina and an unknown native bamboo growing naturally in the Nyungwe forests).

Results of the trial indicated that the three species were not significantly different in terms of stem diameter. However, the number of sprouts that emerged from cuttings differed with species: Bambusa vulgaris producing 22.2 sprouts, Arundinaria alpina 18.1 and the native bamboo producing 15.0 sprouts. On the other hand, the native bamboo had a mean height of $54.0 \mathrm{~cm}$, while Bambusa vulgaris 36.6 and Arundinaria alpina had $30.8 \mathrm{~cm}$. The soaking treatments did not have significant difference on all the parameters evaluated. This reproducible protocol opens new prospects for propagation of bamboo and will go a long way in alleviating the shortage of planting materials and exploiting the enormous potential of bamboo in Rwanda.
\end{abstract}

Key words: Bamboo, propagation, mother stem, sprouts 


\section{INTRODUCTION}

Bamboo belongs to the family of Poaceae/ Gramineae. It is part of the true grass family, and makes up the largest and most productive member. There are approximately 1500 species of bamboo under 87 genera worldwide (Zhou et al., 2005). About 300 species are so far reported from China, 130 species from India, 55 species from the Philippines, 50 species from Thailand, 33 species from Bangladesh, 31 species from Indonesia, 26 species from Papua New Guinea and 12 species from Malaysia (Banik, 1987). The largest forest area under bamboo is in India with 9.57 million hectares of bamboo forests or $12.8 \%$ of the total forest area (Zhou et al., 2005). In China 3.4 million hectares are under bamboo (3\% of total forest area), with a production of 5 million tons. Bamboo has the ability to grow in regions that range from the sub-Sarahan deserts of Africa, to the cold mountain terrain of the Himalayas (Jifan, 1987). It has a long and detailed history and is one of the most versatile plants in the world. The majority of species are native to the tropics of Asia, although one species, Arundinaria gigantea, is native to the United States.

It is one of the most unique and versatile groups of plants known to mankind; the bamboos occupy a special place in the lives of the rural poor, especially in Asia. For almost half the human race in the world, life would be quite hard without bamboo. It is used for food, as a weapon or as a tool, as a cooking instrument or a container, as a musical instrument or as an object of beauty, as shelter and even as medicine (Huang et al, 1988). It is also known to produce very high biomass. One of the most important contributions of bamboo to modern-day man is in the production of paper. Though once called poor man's timber it is no longer cheap. Its use as a long-fiber raw material in the pulp and paper industry is well known and it is one of the most sought-after raw materials in the tropics. (Huang et al, 1988).

Rwanda has the highest rate of deforestation (3.9\% per annum) reported for African countries and, indeed, in the world (MINITERE and CGIS-NUR 2007). It is for this reason that the Rwandan government has decided to put particular effort in the afforestation program. However, this program is severely constrained by several factors including but not limited to lack of 
good quality and adapted planting materials for some tree species like bamboo. There are also few indigenous species of which Arundinaria alpina, predominantly found in the north around Volcano National Park and Bambusa vulgaris in the forests of Crest-Zaire-Nile region of the country. For the country to exploit the potential of bamboo it is imperative to establish a propagation protocol to effectively multiply and supply the required amount of planting materials for large scale plantation.

Conventionally, bamboo is propagated through seed or by vegetative means. Propagation by seed has a number of challenges as some of the species do not produce seed (e.g., Bambusa balcooa and Bambusa vulgaris), and those which do so, often flower at long intervals varying from 30 to 70 years (e.g. Bambusa bambos, B. polymorpha, Dendrocalamus strictus, Melocanna baccifea and Phyllostachys spp.) (Nath et al., 2009).

Vegetative propagation is done by dividing up clumps and their underground stems or cutting up the underground stems (rhizomes) of nonclumping species. However, many species produce extremely large plants and it is not always easy to dig out pieces for propagation. The number of plants produced using the above methods are not adequate (Gupta, 2008) and it is important to make available suitable planting stocks in order to complement efforts to conserve shrinking forest habitats.

\section{MATERIALS AND METHODS}

The study was conducted at Ruheru, Nyaruguru District, in the buffer zone of Nyungwe National Park within the Congo-Nile basin. The area is recognized as a zone of two natural bamboo species, Arundinaria alpina and Oxytenanthera abyssinica. The mean altitude at the site is $2354 \mathrm{~m}$ above sea level. Temperatures at the site are generally cool with an average minimum of $10.9^{\circ} \mathrm{C}$ and an average maximum of $19.6^{\circ} \mathrm{C}$. The mean annual rainfall is $1,744 \mathrm{~mm}$. A major dry season occurs between July and August and a minor dry season takes place between December and January.

\section{METHODOLOGY}

Three bamboo species comprising Arundinaria alpina, Bambusa vulgaris and a native variety were used. Cuttings from three positions (basal, middle and apical) were subjected to soaking in water for $0,6,12,18$ and 24 hours and each treatment comprised of 48 cuttings. 
The field was hand-cultivated and the trial was established in December 2007 in a 0.5 ha plot. The spacing between each cutting was $1.5 \times 1.5 \mathrm{~m}$. Organic manure (farm yard manure) was applied to all plots before planting at 10 t/ha. A Randomised Complete Block Design (RCBD) with 3 replicates of treatments. 45

Analysis of variance (ANOVA) indicated no significant difference between various treatments. Data was subjected to normality test, which showed no uniform distribution. This necessitated using nonparametric tests. Thus, the nonparametric Kruskal-Wallis test was used to analyze the data.

\section{RESULTS}

\section{Effect of soaking bamboo cuttings on growth and development parameters}

The various soaking treatments did not have any significant effect on sprouting, collar diameter and plant height on all the three bamboo species evaluated (Table1)

\section{Effect of original position of cuttings on the mother stem}

The three cutting positions evaluated did not have a significant effect on sprouting, collar diameter and plant height in Arandunaria alpina. However, the cuttings harvested from the middle region had the highest number of sprouts while those harvested from the basal part had the lowest number of sprouts (Table 2).

The three cutting positions evaluated did not have a significant effect on sprouting, collar diameter and plant height in Bambusa vulgaris. However, the cuttings harvested from the middle position gave the highest number of sprouts while the cuttings harvested from the bottom canopy gave the lowest number of sprouts (Table 2).

The three cutting positions evaluated did not have a significant effect on sprouting, collar diameter and plant height in Native bamboo but the cuttings harvested from the bottom gave the highest number of sprouts while the cuttings harvested from the top gave the lowest number of sprouts (Table 2). 
Table 1: Effect of soaking on growth characteristics of bamboo varieties

\begin{tabular}{|l|l|l|l|l|l|l|l|l|l|}
\hline \multirow{2}{*}{$\begin{array}{l}\text { Duration } \\
\text { of soaking } \\
(\text { Hours) }\end{array}$} & \multicolumn{3}{|l|}{ Number of sprouts } & \multicolumn{3}{l|}{ Diameter (cm) } & \multicolumn{2}{l|}{ Plant height (cm) } \\
\cline { 2 - 10 } & Var1 & Var2 & Var3 & Var1 & Var2 & Var3 & Var1 & Var2 & Var3 \\
\hline 0 & $18.67 \mathrm{a}$ & $20.39 \mathrm{a}$ & $13.61 \mathrm{a}$ & $2.89 \mathrm{a}$ & $2.31 \mathrm{a}$ & $1.43 \mathrm{a}$ & $31.54 \mathrm{a}$ & $30.06 \mathrm{a}$ & $38.11 \mathrm{a}$ \\
\hline 6 & $12.28 \mathrm{a}$ & $23.40 \mathrm{a}$ & $10.67 \mathrm{a}$ & $3.66 \mathrm{a}$ & $2.43 \mathrm{a}$ & $1.50 \mathrm{a}$ & $36.83 \mathrm{a}$ & $32.68 \mathrm{a}$ & $40.63 \mathrm{a}$ \\
\hline 12 & $24.56 \mathrm{a}$ & $23.89 \mathrm{a}$ & $20.83 \mathrm{~b}$ & $2.12 \mathrm{a}$ & $2.97 \mathrm{a}$ & $2.70 \mathrm{a}$ & $25.86 \mathrm{a}$ & $36.91 \mathrm{a}$ & $65.51 \mathrm{~b}$ \\
\hline 18 & $16.06 \mathrm{a}$ & $17.28 \mathrm{a}$ & $20.89 \mathrm{~b}$ & $3.60 \mathrm{a}$ & $2.42 \mathrm{a}$ & $2.26 \mathrm{a}$ & $34.79 \mathrm{a}$ & $52.59 \mathrm{a}$ & $57.73 \mathrm{~b}$ \\
\hline 24 & $18.89 \mathrm{a}$ & $26.22 \mathrm{a}$ & $8.83 \mathrm{a}$ & $2.55 \mathrm{a}$ & $2.36 \mathrm{a}$ & $2.30 \mathrm{a}$ & $27.99 \mathrm{a}$ & $30.75 \mathrm{a}$ & $67.94 \mathrm{~b}$ \\
\hline
\end{tabular}

* Ø- Diameter

Var1-Arundinaria alpina

Var2- Bambusa vulgaris

Var3- Native bamboo

Table 2: Effect of position of cuttings on growth characteristics of bamboo varieties

\begin{tabular}{|l|l|l|l|l|l|l|l|l|l|}
\hline \multirow{2}{*}{$\begin{array}{l}\text { Positio } \\
\text { n of } \\
\text { cutting }\end{array}$} & \multicolumn{4}{|l|}{ Number of sprouts } & \multicolumn{3}{l|}{ Mean Ø* (cm) } & \multicolumn{3}{l|}{ Mean height (cm) } \\
\cline { 2 - 11 } & Var1 & Var2 & Var3 & Var1 & Var2 & Var3 & Var1 & Var2 & Var3 \\
\hline Top & $18.70 \mathrm{a}$ & $23.63 \mathrm{a}$ & $10.10 \mathrm{~b}$ & $2.64 \mathrm{a}$ & $7.71 \mathrm{a}$ & $2.46 \mathrm{a}$ & $23.38 \mathrm{a}$ & $45.69 \mathrm{a}$ & $59.89 \mathrm{a}$ \\
\hline Middle & $21.73 \mathrm{a}$ & $25.70 \mathrm{a}$ & $13.83 \mathrm{ab}$ & $2.56 \mathrm{a}$ & $3.33 \mathrm{a}$ & $2.00 \mathrm{a}$ & $32.83 \mathrm{a}$ & $34.57 \mathrm{a}$ & $53.41 \mathrm{a}$ \\
\hline Bottom & $13.83 \mathrm{a}$ & $17.37 \mathrm{a}$ & $20.97 \mathrm{a}$ & $3.43 \mathrm{a}$ & $2.43 \mathrm{a}$ & $1.85 \mathrm{a}$ & $35.31 \mathrm{a}$ & $29.81 \mathrm{a}$ & $51.05 \mathrm{a}$ \\
\hline
\end{tabular}

* Ø- Diameter

Var1-Arundinaria alpina

Var2- Bambusa vulgaris

Var3- Native bamboo

\section{Effect of variety on different growth and development parameters}

The three varieties were significantly different in sprouting and plant height. Bambusa vulgaris had the highest number of sprouts, which was significantly $(\mathrm{p}=0.001)$ different from Arundinaria alpine and the native bamboo. On the other hand, the native bamboo had the highest height which was significantly $(\mathrm{p}=0.001)$ different from the other varieties (Table 3 ).

Table 3: Effect of variety on different growth characteristics in Bamboo

\begin{tabular}{|c|c|c|c|}
\hline Variety & Number of sprouts & Mean Ø (cm) & Mean height (cm) \\
\hline Arundinaria alpina & $18.09 \mathrm{~b}$ & $2.88 \mathrm{a}$ & $30.78 \mathrm{~b}$ \\
\hline Bambusa vulgaris & $22.23 \mathrm{a}$ & $4.46 \mathrm{a}$ & $36.57 \mathrm{~b}$ \\
\hline Native bamboo & $14.97 \mathrm{~b}$ & $2.05 \mathrm{a}$ & $53.97 \mathrm{a}$ \\
\hline
\end{tabular}

Rwanda Journal ISSN 2305-2678 Volume 28, Series E, 2012 : Agricultural Sciences 


\section{DISCUSSION AND CONCLUSION}

Bamboos can be propagated either by seeds or vegetatively. Propagation by seed is seldom used because of the rare and irregular flowering of most bamboo species. Besides, most bamboos produce infertile seeds or they rarely develop seeds. Moreover, most bamboos generally die soon after flowering (Nath et al., 2009).

Among the vegetative parts, the one node cutting method is at present the most widely used because it is the most economical and easiest to handle. This method is recommended for raising planting stocks of the genera Bambusa, Dendrocalamus and Gigantochloa (Manipula et al., 1990). Propagation of bamboo using cuttings has more benefits than the conventional methods. The three cutting positions evaluated did not have a significant effect on sprouting, collar diameter and plant height.

However, the cuttings harvested from the middle region had the highest number of sprouts while those harvested from the basal part had the lowest number of sprouts. This concurs with Malab et al. (1995) who made similar observations when working with Bambusa vulgaris and Dendrocalamus spp.

The soaking pre-treatment did not have a significant difference in the number of sprouts. However, Bambusa vulgaris had the highest number of sprouts. Bambusa vulgaris has been found to be more prolific than most of the bamboo species evaluated by Cariño (1990) and Ramoran et al. (1993). There are no publications on the use of cuttings to propagate Arundinaria alpina and for the first time, the current study showed that it is possible to use cuttings.

In this trial the native bamboo had the highest mean height in all the treatments. A possible explanation for this is the fact that the trial was conducted in Nyungwe forest which is its natural habitat.

In conclusion, it may be stated that the best part of bamboo to use when propagating the three bamboo varieties is the middle part and soaking cuttings in water has no added advantage. However, it is recommended that further work be replicated in other agro ecological zones and crucial parameters like rooting be evaluated. 


\section{Acknowledgment}

The authors sincerely thank Institut des Sciences Agronomiques du Rwanda (ISAR) Management for availing funds to carry out this work. The assistance of all the staff in the wood technology program at ISARRUHANDE research station is highly appreciated.

\section{REFERENCES}

1. Banik, R. 1987. Techniques of bamboo propagation with special reference to pre-rooted and pre-rhizomed branch cuttings and tissue culture. 160-169. In A.N. Rao, G. Dhanarajan \& C.B. Sastry (Eds.). Recent Research on Bamboos. The Chinese Academy of Forestry and International Development Research Centre, Singapore.

2. Cariño, F.C. (1990). Marcotting of Bambusa vulgaris Schrad, Using polyacrylamide. Paper presented at the Second National Bamboo R \& D Symposium held at the ERDB Auditorium, College, Laguna on Dec 14. 1990.

3. Gupta A. K., 2008, National bamboo Mission: Aholistic scheme for development of Bamboo Sector in Tripura. Indian Forester, 134(3): 305324.

4. Huang, L.C.; Chen, W.L. \& Huang, B.L. 1988. Tissue culture investigations of bamboo. II. Liquid suspension cultures of Bambusa, Phyllostachys and Sasa cells. Bot. Bull. Acad. Sinica 29: 177-182.

5. Jifan, Z. (1987). Bamboo development in China. 24-25. In A.N. Rao, G. Dhanarajan \& C.B. Sastry (Eds.). Recent Research on Bamboos. The Chinese Academy of Forestry and International Development Research Centre, Singapore.

6. Malab, S.C., S. Ma. Pablico and L.G. Battad. (1995). Bamboo planting material production and nursery management. Paper presented during the National-Bamboo Symposium on Dec. 19-21, 1995 held at the ERDB, Auditorium, College, Laguna.

7. Manipula, B. M., N. So. Gianan and F. D. Virtucio. (1990). Survival and growth of culm cutting and whole culm of Gigantochloa atter as affected by age and culm portion. Paper presented at the Second 
National Bamboo R \& D Symposium held at the ERDB Auditorium, College, Laguna. December 14, 1990.

8. MINITERE and CGIS-NUR (2007). Final report on the Mapping of Rwandese forests, Volume 1. The Ministry of Lands, Environment, Forests, Water and Natural Resources (MINITERE) and The Geographic Information Systems \& Remote Sensing Research and Training Center of the National University of Rwanda (CGIS - NUR).

9. Nath S., Das R., Chandra R., and Sinha A., (2009), Bamboo based agroforestry for marginal lands with special reference to productivity, market trend and economy.In: Agroforestry in Jharkhand, Envis Jharkhand News .80-96.

10. Ramoran, E.B., A.B. Lapis and F.D. Virtucio. (1993). Production of planting stocks from rhizome offsets, culm cuttings and branch cuttings of selected bamboo species. Sylvatrop No. 2. Seethalakshmi et al, 1983.

11. Zhou Ben-Zhi, FU Mao-yi, XIE Jin-Zhong, YANG Xiao-sheng and LI Zheng-cai, (2005). Ecological function of Bamboo forest: Research and application. Research Institute of Subtropical forestry, Chinese Academy of forestry, Fuyang, Zhejiang. China. 